ASEE: Session 2004-782

\title{
Transportation Education at Colleges and Universities in the Mountain States
}

\author{
Wayne D. Cottrell, Assistant Professor \\ Department of Civil and Environmental Engineering \\ 122 South Central Campus Drive, Room 104 \\ University of Utah \\ Salt Lake City, Utah 84112-0561 \\ (801) 587-9015 (phone); (801) 585-5477 (fax) \\ wcottrel@eng.utah.edu
}

\begin{abstract}
This study investigates transportation engineering and planning education at two- and four-year colleges and universities located within the mountain region of the U.S. As of the 2003-2004 academic year, 40 of the 185 schools in the region were teaching at least one course in transportation; 36 of these were four-year institutions. A total of 32 of the 40 institutions were offering a degree in a transportation-related field. The combined results of three different surveys of transportation professionals, each performed by other researchers, along with input from the author, identified a set of 15 essential topics to be covered in a comprehensive transportation education program. None of the institutions in the study region were offering courses in all 15 areas, but four schools were covering over $50 \%$ of the essential topics. A total of 247 undergraduate and graduate transportation courses were being taught throughout the study region; the most "popular" type was in air transportation. Other common subjects were in pavement design and maintenance, highway engineering and construction, and traffic engineering. Economics and finance, public transit, and law and regulations were somewhat "unpopular" in that few institutions offered courses in these. Research activity was rated based on institutional involvement in the annual meeting of the Transportation Research Board. A total of 18 schools participated in a session or workshop during the 2002 or 2003 meetings. Seventeen institutions were identified as representing the "top tier" of schools having transportation programs in the mountain region. Further study would be needed to distinguish between the quality of transportation instruction and research provided at these 17 institutions. Only two interdisciplinary transportation programs were identified, despite the recognized need for multidisciplinary approaches to addressing transportation problems. This paper may be of use to educators who are either developing or modifying their transportation programs, prospective students, and researchers who may be interested in doing similar studies of other disciplines or regions. Because of ongoing changes in faculty and courses, this and similar studies should be updated regularly.
\end{abstract}

\section{Study Objective}

The objective of this study was to evaluate the coverage and depth of transportation engineering and planning education at four-year colleges and universities in the mountain region of the U.S. 
as of the 2003-2004 academic year. The mountain region (i.e., Mountain Time zone) includes all of six states (Arizona, Colorado, Montana, New Mexico, Utah, and Wyoming), the eastern portion of Oregon, the southern portion of Idaho, western portions of four states (Kansas, Nebraska, North Dakota and South Dakota), and the far-western corner of Texas. The study did not attempt to evaluate the quality of transportation education at these institutions. Program coverage considers such characteristics as the number of courses offered in essential topics, the number of full-time transportation faculty, and the level of transportation research activity. Program quality considers a number of other factors that are not fully addressed in this paper. For example, the National Research Council, in year 1995 ratings of research doctoral programs, assessed faculty scholarliness, educational effectiveness, the five-year trend in program quality, the visibility of the program, the number of citations in the literature attributable to the program's faculty, citation "density" (total citations divided by the number of faculty), and the total number of faculty (1). The U.S. News and World Report, in its annual rankings of graduate programs, considers reputation ranks by academics, engineers and recruiters, the average Graduate Record Exam (GRE) and Standard Aptitude Test (SAT) scores of admitted students, student acceptance rates, the number of Ph.D. students per faculty member, the percent of faculty in the National Academy of Sciences, total research expenditures (total and per faculty member), and the number Ph.D.s granted (2). Angus et al. (3) evaluated chemical engineering programs using four measures of quality: the number of publications by department faculty, the number of citations of their work, research funding, and faculty honors.

This study, in contrast, is oriented toward quantity rather than quality. The measures of program breadth and extent include the number of courses taught in essential subject areas, the total number of courses taught, the number of degrees granted in transportation-related fields, the presence of an established transport research support mechanism, and the amount of transportation research output. This overview of the study approach is a caveat to the reader who may be expecting an evaluation of program quality. A similar study was undertaken four years ago of transportation programs in the western U.S. (4). At that time, one purpose of the study was to guide the development of the transportation program at the author's institution. One objective of the current paper is to update the previous study. A second objective is to ascertain how well the programs in the mountain region are striving to meet the needs of the transportation engineering and planning profession. The results of the study are intended to serve as a guide to students, educators, researchers, collaborators, and practitioners who are working in or who may be interested in transportation engineering and planning. The study may also serve as a guide for similar studies in other regions of the U.S. and in other countries. Any such study should be updated regularly to remain current with faculty and curricula.

Transportation has been defined as the movement of people, goods and information from one place to another (5). Transportation engineering is defined as the planning, design, operation, maintenance and management of streets and highways, public transit systems, airports, railroads, ports, and harbors (6). This study examines the extent to which undergraduate programs in the mountain states introduce students to these topics, and the breadth of coverage that undergraduate and graduate programs provide for the most requisite of these topics.

\section{Background}

In 1984, the Transportation Research Board (TRB) sponsored a conference on transportation education and training. One presenter noted that education in transportation engineering and

Proceedings of the 2004 American Society for Engineering Education Annual Conference \& Exposition Copyright @ 2004, American Society for Engineering Education 
planning at U.S. universities was most commonly found in civil engineering (now civil and environmental engineering, or CEE) departments (7). By 1998, in response to the broadened, multimodal needs of federal transportation legislation, it was ascertained that multiple academic departments needed to be involved in transportation education to a greater extent than in previous years (8). Similarly, Van Zuylen (9) concluded that transportation problems were now "so complex that expertise in more than one academic discipline is needed to find solutions." Although most transportation specialists have traditionally been found in CEE departments, academicians with teaching and research interests in transport are also based in business, economics, geography, industrial or systems engineering, political science, public administration or policy, social studies, urban affairs, urban planning, and interdisciplinary departments. Air transportation specialists can be found in aerospace or aviation departments, and bridge, highway and pavement specialists might be found in construction or structures departments. Further, the need to address the human behavior components of transportation finds specialists in education, psychology, sociology, and even anthropology departments. Beimborn (7) noted that several schools had formed transportation centers to foster the integration of different parts of the university. A select few universities had built strong programs in transportation. The success of a program was heavily dependent on the ability to develop and maintain research centers to support educational activities. Pignataro and Hoel (8) found that some university administrations were not supportive of the formation of interdisciplinary programs, leaving transportation specialists within separate departments to act independently. This paper explores the extent to which multidisciplinary approaches to transportation are being taken in the study region. The paper does not attempt to examine administrative issues.

\section{Identification of Essential Transportation Topics}

During the late 1980s, an Institute of Transportation Engineers (ITE) technical committee addressed the graduate school curriculum needs of transportation engineering students. The committee received survey responses from 187 transportation engineers, supervisors and educators. The respondents listed the courses that they felt were the most important components of a graduate transportation engineering program (10). A companion report on undergraduate transportation engineering courses had previously been published (11). Earlier, Khisty (12) surveyed 50 practitioners to suggest undergraduate transportation engineering topics.

In ITE's 1990 report, 49 topics were suggested. The number of respondents suggesting each topic was categorized according to engineer, supervisor or educator. Consensus among all three groups was reached on 17 of the topics. Turnbull (13) developed a list of 21 desirable knowledge and skill areas in transportation planning from a survey of 46 professionals in the public, private and academic sectors. Handy et al. (14) received responses from 360 transportation planning and engineering professionals on the training required for their jobs. About $60 \%$ of the respondents worked for local, regional, state or federal agencies, while $40 \%$ were consultants. The Handy et al. respondents listed topics that are entirely within the transportation planning arena, although separate, full courses were suggested in several, specialized areas. Combining the ITE consensus topics, additional subjects suggested by both Turnbull's survey and two of the three ITE survey groups, and the "full-course" needs of the Handy et al. respondents, then merging similar subjects, produces the following list of twelve "essential" transportation topics: 
- General (introduction, transportation characteristics)

- Analytical methods (demand forecasting, queuing theory)

- Computer applications and intelligence

- Economics and finance

- Environmental issues (air quality, emissions, fuel)

- Geography of transportation

- Highways (design, engineering)

- Public transportation planning

- Traffic engineering

- Transportation-land use planning

- Transportation planning (neighborhood, regional)

- Transportation laws, regulations and administration

The topics of consensus do not include any air transport, nonmotorized transport, logistics, railroad, transport facilities design, transportation safety, waterborne transport, bridge design, or pavement courses. The Handy et al. respondents listed bicycle-pedestrian planning and transport safety as needed training areas, but their sentiment was that full courses were not needed in these. The topics that were omitted may have resulted from the content of the survey questions, the fields of specialty of the survey respondents, the objectives of the surveyors, a general feeling that these areas are highly specialized, or a general lack of interest in these subjects at the time.

The author elected to add pavement design and management as a $13^{\text {th }}$ essential topic, given the preponderance of academic and professional specialists in these areas, and the clear importance of highway surface quality. Highway materials professionals did not participate in the Turnbull or Handy et al. surveys, and were, perhaps, not adequately represented in the ITE survey. A $14^{\text {th }}$ essential topic, air transportation, was added in recognition of the clear importance of this mode. Finally, freight transportation was added as a $15^{\text {th }}$ topic; as stated earlier, the movement of goods is embedded within the definition of transport. The Handy et al. respondents listed "professional ethics" and "urban design" as full-course needs; since these subjects are not specific to transportation, the author chose not to include them in the list.

\section{Setting}

This study considered transportation engineering and planning education at four-year colleges and universities in the mountain states, including all states and portions thereof lying within the Mountain Time zone. The study did not cover a larger area to retain a manageable scope of work. As of 2003, a total of 123 public and independent four-year institutions in the mountain states offered bachelor's degrees, while 45 offered graduate degrees $(15,16)$. Also, 62 two-year colleges were offering associate's degrees or certificates (17). A total of 20 institutions were offering degrees in CEE; 14 of these had bachelor's and graduate degree programs, while six offered bachelor's degrees only. A total of seven institutions were offering degrees in city and regional planning (CRP); two of these had undergraduate and graduate programs, and three had graduate programs only. Three schools were offering bachelor's degrees in civil engineering technology (CET), and two schools were offering a graduate degree in transportation management or systems (TMS). Four schools were offering bachelor's degrees in aviation management (AVI); in logistics and materials management (LOG), one school was offering a 
bachelor's degree and two were offering graduate degrees. Associate's degrees were being offered in CET at twelve schools and in transportation technology (TET) at two schools. A summary of the degrees being offered within the study region is provided in Table 1.

Table 1. Mountain Region Colleges \& Universities Offering Degrees in Transportation-Related Fields

\begin{tabular}{|c|c|c|c|c|c|c|c|}
\hline College or University & AVI & CRP & CEE & CET & LOG & TET & TMS \\
\hline Arizona St U (Tempe) & & $\mathrm{BM}$ & BMD & & MD & & $\mathrm{CM}$ \\
\hline Boise St U (ID) & & & $\mathrm{BM}$ & & & & \\
\hline Brigham Young U (Provo, UT) & & & BMD & & & & \\
\hline Brigham Young U - Idaho (Rexburg) & & & & $\mathrm{A}$ & & & \\
\hline Carroll Coll (Helena, MT) & & & $\mathrm{B}$ & & & & \\
\hline Central Arizona Coll (Coolidge) & & & & $\mathrm{A}$ & & & \\
\hline Colorado Sch of Mines (Golden) & & & $\mathrm{B}$ & & & & \\
\hline Colorado St U (Ft. Collins) & & & BMD & & & & \\
\hline Colorado St U - Pueblo & & & & $\mathrm{B}$ & & & \\
\hline Colorado Tech U (Colorado Springs) & & & & & $\mathrm{M}$ & & \\
\hline Eastern Arizona Coll (Thatcher) & & & & $\mathrm{A}$ & & & \\
\hline Embry-Riddle Aeronautical U (Prescott, AZ) & $\mathrm{B}$ & & & & & & \\
\hline Idaho St U (Pocatello) & & & & $\mathrm{A}$ & & & \\
\hline Laramie County Comm Coll $(W Y)$ & & & & $\mathrm{A}$ & & & \\
\hline Metro St Coll of Denver $(\mathrm{CO})$ & $\mathrm{B}$ & & & $\mathrm{B}$ & & & \\
\hline Montana St U - Bozeman & & & $\mathrm{BD}$ & & & & \\
\hline Montana St U - Northern (Havre) & & & & $\mathrm{AB}$ & & & \\
\hline Montana Tech of The U of Montana (Butte) & & & $\mathrm{B}$ & & & & \\
\hline New Mexico Military Inst (Roswell) & & & & $\mathrm{A}$ & & & \\
\hline New Mexico St U (Las Cruces) & & $\mathrm{B}$ & BMD & & & & \\
\hline Northern Arizona U (Flagstaff) & & & $\mathrm{B}$ & & & & \\
\hline Phoenix Coll $(A Z)$ & & & & $\mathrm{A}$ & & & \\
\hline Pueblo Comm Coll $(\mathrm{CO})$ & & & & $\mathrm{A}$ & & & \\
\hline Rocky Mountain Coll (Billings, MT) & $\mathrm{B}$ & & & & & & \\
\hline Salt Lake Comm Coll (UT) & & & & A & & A & \\
\hline South Dakota Sch of Mines \& Tech (Rapid City) & & & $\mathrm{B}$ & & & & \\
\hline Southwestern Indian Polytech Inst $(N M)$ & & & & A & & & \\
\hline Trinidad St Jr Coll $(\mathrm{CO})$ & & & & $\mathrm{A}$ & & & \\
\hline U of Arizona (Tucson) & & $\mathrm{BM}$ & BMD & & & & \\
\hline U of Colorado - Boulder & & & BMD & & & & \\
\hline U of Colorado - Denver & & $\mathrm{M}$ & BMD & & & & \\
\hline U of Denver $(\mathrm{CO})$ & & & & & & & $\mathrm{M}$ \\
\hline U of Montana - Missoula & & $\mathrm{B}$ & & & & & \\
\hline U of New Mexico (Albuquerque) & & $\mathrm{M}$ & BMD & & & & \\
\hline U of Texas - El Paso & & & $\mathrm{BM}$ & & & & \\
\hline U of Utah (Salt Lake City) & & & BMD & & & & \\
\hline U of Wyoming (Laramie) & & & BMD & & & & \\
\hline U.S. Air Force Acad (USAF Academy, CO) & & & $\mathrm{B}$ & & & & \\
\hline Utah State U (Logan) & & $\mathrm{M}$ & BMED & & & & \\
\hline Utah Valley St Coll (Orem) & & & & & & A & \\
\hline Weber St U (Ogden, UT) & & & & & $\mathrm{B}$ & & \\
\hline Westminster Coll (Salt Lake City, UT) & $\mathrm{B}$ & & & & & & \\
\hline
\end{tabular}

NOTE: $\mathrm{AVI}=$ aviation; $\mathrm{CEE}=$ civil $\&$ environmental engineering; $\mathrm{CET}=$ civil engineering technology; $\mathrm{CRP}=$ city $\&$ regional planning; LOG $=$ logistics; TET $=$ transportation technology; TMA = transportation management or systems; A = associate's degree; $\mathrm{B}=$ bachelor's degree; $\mathrm{C}=$ certificate; $\mathrm{M}=$ master's degree; $\mathrm{E}=$ civil engineer's degree; $\mathrm{D}=$ doctorate.

Proceedings of the 2004 American Society for Engineering Education Annual Conference \& Exposition Copyright (C) 2004, American Society for Engineering Education 
In the entire U.S., 236 institutions were offering one or more degrees in CEE; 130 were offering one or more degrees in CRP; 53 in AVI, 42 in CET, 27 in LOG, and 17 in TMS, as of 2003. Also, nationwide, there were 32 programs in transportation and highway engineering, 16 in aviation and airway science, 4 in transportation technology, and one in transportation materials $(16,17)$. Schools in the mountain region represented $8.5 \%$ of those in the U.S. granting CEE degrees; $5.4 \%$ of those granting CRP degrees, $7.5 \%$ of those with AVI, $7.1 \%$ of those with CET, $3.7 \%$ of those with LOG, $5.9 \%$ of those with TMS, and none of the other transportation-related programs. To establish a context, the population of the study region, according to the 2000 census, was 17.4 million (15). This represented $6.2 \%$ of the U.S. population. The area of the region was 2.1 million sq $\mathrm{km}$, representing nearly one-fourth of the U.S.' area. The number of undergraduate CEE, CRP, AVI, CET, LOG, and TMS programs in the mountain region was, therefore, commensurate with the population base, although the colleges and universities were, perhaps, more widely scattered than in other regions of the country.

\section{Teaching}

Information on the transportation courses at the 42 mountain region institutions offering degrees in transportation-related fields was obtained from online university catalogs and program descriptions. Academic year 2003-2004 materials were obtained for all of the colleges and universities. Of the 42 institutions, 32 were offering at least one course in transportation. A scan of the other 143 two- and four-year institutions in the mountain region uncovered transportation coursework at eight schools. These eight schools were not awarding degrees in transportationrelated fields, but were providing transportation coursework as a specialty within a broader discipline. Several business departments, for example, were teaching one or more transportation courses.

A total of 40 institutions in the mountain region were offering one or more transportation courses as of the 2003-2004 academic year; this was $21.6 \%$ of all two- and four-year schools in the study area. The institutions are listed in Table 2. A total of 247 undergraduate, graduate, undergraduate-graduate transportation courses were being taught within 15 different academic disciplines. The 247 courses excluded driver training, motor vehicle and aircraft technology, motor vehicle and aircraft maintenance, air military, freight inventory and supply chain, pipeline, and tourism and recreational management classes. Distance learning courses were also excluded. The greatest portion of the courses - 108 or $43.9 \%$-- was found in CEE departments. Aviation programs were providing 49 or $19.9 \%$ of the courses, special transportation departments were offering 21 or $8.5 \%$ of the courses, and civil or transportation technology programs were teaching 13 or $5.3 \%$ of the courses. The other 50 courses were scattered among eleven different disciplines, including business, city and regional planning, construction management, education, environmental policy, geography, history, industrial or systems engineering, K-12 school administration, law, and logistics.

Two of the 40 institutions featured special transportation-only departments. One was a railroading department at Montana State University - Northern; this department was not awarding a degree. The other was an intermodal transportation institute at the University of Denver that was unique to the study region. A master of science degree in intermodal transportation management was being awarded.

All but two of the 40 institutions offering coursework in transportation were on a semester system. Courses offered at the two schools on the quarter system - Colorado Technical

Proceedings of the 2004 American Society for Engineering Education Annual Conference \& Exposition Copyright (C) 2004, American Society for Engineering Education 
Table 2. Number of Transportation Courses by Department: Colleges \& Universities in the Mountain Region

\begin{tabular}{|c|c|c|c|c|c|c|c|c|c|c|c|c|c|c|c|c|}
\hline College or University & Calendar & $\mathbf{A}$ & B & C & $\mathbf{E}$ & G & $\mathrm{H}$ & I & $\mathbf{K}$ & $\mathbf{L}$ & $\mathbf{M}$ & $\mathbf{R}$ & $\mathbf{T}$ & $\mathbf{U}$ & $\mathrm{V}$ & $\mathbf{W}$ \\
\hline Arizona St U & Semester & 4 & 5 & 12 & & 2 & & & & & & & & 3 & & \\
\hline Black Hills St U* & Semester & & & & & & & & & & & & 1 & & & \\
\hline Boise St U & Semester & & & 7 & 2 & & & & & & 1 & & & & & \\
\hline Brigham Young U & Semester & & & 6 & & & & & & & & & & & & \\
\hline Carroll Coll & Semester & & & 1 & & & & & & & & & & & & \\
\hline Chadron St Coll* & Semester & & & & & & & & & & & & 2 & & & \\
\hline Colorado St U & Semester & & & 1 & & & & & & & & & & & & \\
\hline Colorado St U - Pueblo & Semester & & & & & & & & & & & & 2 & & & \\
\hline Colorado Tech U & Quarter & & & & & & & & & $?$ & & & & & & \\
\hline DeVry U $(C O)^{*}$ & Semester & & 1 & & & & & & & & & & & & & \\
\hline DeVry U $(A Z)^{*}$ & Semester & & 1 & & & & & & & & & & & & & \\
\hline $\begin{array}{l}\text { Embry-Riddle } \\
\text { Aeronautical U }\end{array}$ & Semester & 3 & & & & & & & & & & & & & & \\
\hline Idaho St U & Semester & & & 2 & & & & & & & & & 2 & & & \\
\hline Metro St Coll of Denver & Semester & 19 & & & & 1 & & & & & & & & & & \\
\hline Montana St U - Bozeman & Semester & & & 7 & & & & & & & & & & & & \\
\hline Montana St U - Northern & Semester & & & 1 & 5 & & 1 & & 1 & & & 1 & 1 & & & \\
\hline $\begin{array}{l}\text { Montana Tech of The U of } \\
\text { Montana }\end{array}$ & Semester & & & & & & & & & & & & 1 & & & \\
\hline $\begin{array}{l}\text { New Mexico Inst of } \\
\text { Mining \& Tech* }\end{array}$ & Semester & & & 1 & & & & & & & & & & & & \\
\hline New Mexico St U & Semester & & & 1 & & 1 & & & & & & & & 1 & & \\
\hline Northern Arizona U & Semester & & & 2 & & & & & & & & & & & & \\
\hline Phoenix Coll & & & & & & & & & & & & & 2 & & & \\
\hline Pueblo Comm Coll & Semester & & & & & & & & & & & & 1 & & & \\
\hline Rocky Mountain Coll & Semester & 10 & & & & & & & & & & & & & & \\
\hline Salt Lake Comm Coll & Semester & & & & & & & & & 7 & & & & & & \\
\hline $\begin{array}{l}\text { South Dakota Sch of Mines } \\
\& \text { Tech }\end{array}$ & Semester & & & 1 & & & & & & & & & & & & \\
\hline Southern Utah U* & Semester & & & & & & & & & & & & 1 & & & \\
\hline U of Arizona & Semester & & 1 & 7 & & & & 1 & & 1 & & & & 2 & & \\
\hline U of Colorado - Boulder & Semester & & & 1 & & & & & & & & & & 2 & & \\
\hline U of Colorado - Denver & Semester & & & 13 & & & & & & & & & & 2 & & \\
\hline U of Denver & Quarter & & 2 & & & 1 & & & & & & 20 & & & 1 & 6 \\
\hline U of Montana - Western* & Semester & & & & & & & & & & & & 1 & & & \\
\hline U of New Mexico & Semester & & & 9 & & & & & & & & & & 1 & & \\
\hline U of Texas - El Paso & Semester & & & 3 & & & & & & & & & & & & \\
\hline U of Utah & Semester & & & 12 & & & & & & & & & & & & \\
\hline U of Wyoming & Semester & & & 11 & & 1 & & & & & & & & & & \\
\hline U.S. Air Force Acad & Semester & & & 1 & & & & & & & & & & & & \\
\hline Utah St U & Semester & & & 9 & & & & & & & & & & & & \\
\hline Utah Valley St Coll & Semester & 7 & & & & & & & & & & & & & & \\
\hline Weber St U & Semester & & & & & & & & & 2 & & & & & & \\
\hline Westminster Coll & Semester & 6 & & & & & & & & & & & & & & \\
\hline TOTALS & & 49 & 10 & 108 & 7 & 6 & 1 & 1 & 1 & 10 & 1 & 21 & 14 & 11 & 1 & 6 \\
\hline
\end{tabular}

$\mathrm{A}=$ aviation; $\mathrm{B}$ = business or management; $\mathrm{C}=$ civil \& environmental engineering; $\mathrm{E}=$ education; $\mathrm{G}$ = geography; $\mathrm{H}=$ history; $\mathrm{I}=$ industrial or systems engineering; $\mathrm{K}=\mathrm{K}-12$ administration; $\mathrm{L}=$ logistics; $\mathrm{M}=$ construction management; $\mathrm{R}=$ railroading or "intermodal" transportation; $\mathrm{T}=$ technology (civil or general); $\mathrm{U}=$ urban or city \& regional planning; $\mathrm{V}=$ environmental policy; $\mathrm{W}=$ law; $*=$ school does not offer a degree in a transportation-related field, but has one or more transportation courses. 
University and the University of Denver - were, for the purposes of this research, "worth" twothirds of semester-length courses, based on the duration of the associated terms. Course "worth" can further vary according to the number of weekly lesson and laboratory hours. The research conducted for this paper, however, did not examine the courses to this level of detail.

Table 3 summarizes the transportation course offerings according to the 15 essential topics listed earlier. A total of $210(85.0 \%)$ of the 247 courses were in the essential areas. At least two courses were being taught in each of the 15 essential topics. The dominant specialty was air transportation, with 56 of the courses, followed by pavement engineering and maintenance, with 26 of the courses, highway engineering and construction, with 23 , traffic engineering, with 20, analytical methods (demand forecasting, optimization, linear programming), with 18 , introductory or general transportation, with 17 , freight transport, with 16 , and community or regional transportation planning, with 14 . Between two and six courses were being offered in each of the following subject areas: intelligence, economics and finance, geography, public transportation, land use planning, laws and regulations.

The topics of 36 of the courses were not in the essential areas. Eleven of these courses were in transportation safety; five were related to labor and management, four were specific to railroads, three emphasized bridge design, and three concentrated on transportation power and energy requirements. Courses were also being offered in hazardous materials, maintenance, and policy. The relative popularity of transportation safety courses is in conflict with the finding of Handy et al. (14), whose survey of transportation professionals revealed that an entire course in safety was not needed. The indication is that, at the pertinent institutions, transportation safety is "important" enough to warrant separate courses; the need for full courses, however, may not be widely supported in industry.

The overall assessment of the transportation courses being taught within the mountain region is that there is strength in traditional, technical areas such as highway engineering, traffic engineering, pavement design, and analytical methods. Air transport is also well represented. There is some weakness, though, in non-highway and planning-support courses, such as economics and finance, public transportation, and laws and regulations. It is likely that small programs with limited faculty support are unable to offer courses in a wide variety of topics. One full-time faculty member, for example, can probably teach no more than four to six different courses, implying that at least three transportation instructors are needed to cover all 15 essential topics. When considering that many full-time faculty are obligated to teach at least one undergraduate "service" course per year, then a minimum of four transportation instructors is needed.

The 40 institutions offering courses in transportation were examined according to each's coverage of the 15 essential topics. The University of Denver was offering coursework in 11 of the 15 areas; this was the greatest extent of coverage of the essential topics of any of the institutions. Arizona State University had courses in 10 of the 15 areas; the University of Arizona and the University of Colorado at Denver were each offering courses in 8 of the 15 areas. The University of Utah and Utah State University were covering 7 of the 15 areas, while Boise State University, Brigham Young University, and Montana State University - Bozeman were each offering coursework in 6 of the 15 areas. The University of Wyoming had 5 of the 15 topics covered, and the Metropolitan State College of Denver was covering 4 of the 15 topics. At each institution, courses in the essential areas were being offered by a variety of departments and programs. 
Table 3. Transportation Courses in Essential Areas: Colleges \& Universities in the Mountain Region

\begin{tabular}{|c|c|c|c|c|c|c|c|c|c|c|c|c|c|c|c|c|}
\hline College or University & 1 & 2 & 3 & 4 & 5 & 6 & 7 & 8 & 9 & 10 & 11 & 12 & 13 & 14 & 15 & $\mathbf{O}$ \\
\hline Arizona St U (Tempe) & 2 & 1 & & & 1 & 2 & 2 & & 2 & & 1 & & 8 & 4 & 4 & \\
\hline Black Hills St U (Spearfish, SD) & & & & & & & & & & & & & & & & 1 \\
\hline Boise St U (ID) & 1 & & 1 & & & & 1 & & 2 & & 1 & & 2 & & & 1 \\
\hline Brigham Young U (Provo, UT) & 1 & 1 & & & & & 1 & & 1 & 1 & & & 1 & & & 1 \\
\hline Carroll Coll (Helena, MT) & 1 & & & & & & & & & & & & & & & \\
\hline Chadron St Coll $(N E)$ & & & & & & & 1 & & & & & & & & & 1 \\
\hline Colorado St U (Ft. Collins) & 1 & & & & & & & & & & & & & & & \\
\hline Colorado St U - Pueblo & & & & & & & & & & & & & 1 & & & 1 \\
\hline DeVry U (Colorado Springs, CO) & & & & & & & & & & & & & & & 1 & \\
\hline DeVry U (Phoenix, $A Z$ ) & & & & & & & & & & & & & & & 1 & \\
\hline $\begin{array}{l}\text { Embry-Riddle Aeronautical U } \\
\text { (Prescott, } A Z \text { ) }\end{array}$ & & & & & & & & & & & & & & 3 & & \\
\hline Idaho St U (Pocatello) & & & & & & & 4 & & & & & & & & & \\
\hline Metro St Coll of Denver $(\mathrm{CO})$ & & & & & & 1 & & & & 1 & & & & 19 & 1 & \\
\hline Montana St U - Bozeman & 1 & 2 & 1 & & & & 1 & & 1 & & & & 1 & & & \\
\hline Montana St U - Northern (Havre) & & & & & & & 1 & & & & & & & & & 10 \\
\hline $\begin{array}{l}\text { Montana Tech of The U of } \\
\text { Montana (Butte) }\end{array}$ & & & & & & & & & & & & & 1 & & & \\
\hline $\begin{array}{l}\text { New Mexico Inst of Mining \& } \\
\text { Tech (Socorro) }\end{array}$ & 1 & & & & & & & & & & & & & & & \\
\hline New Mexico St U (Las Cruces) & & 1 & & & & 1 & 1 & & & & & & & & & \\
\hline Northern Arizona U (Flagstaff) & & & & & & & 1 & & 1 & & & & & & & \\
\hline Phoenix Coll $(A Z)$ & & & & & & & 1 & & 1 & & & & & & & \\
\hline Pueblo Comm Coll $(\mathrm{CO})$ & & & & & & & & & & & & & 1 & & & \\
\hline $\begin{array}{l}\text { Rocky Mountain Coll (Billings, } \\
M T)\end{array}$ & & & & & & & & & & & & & & 10 & & \\
\hline Salt Lake Comm Coll (UT) & & & & & & & & & & & & 1 & & & 5 & 1 \\
\hline $\begin{array}{l}\text { South Dakota Sch of Mines \& } \\
\text { Tech (Rapid City) }\end{array}$ & & & & & & & 1 & & & & & & & & & \\
\hline Southern Utah U (Cedar City) & & & & & & & & & & & & & & & & 1 \\
\hline U of Arizona (Tucson) & 1 & 2 & & & & & 1 & 1 & 1 & 1 & 1 & & & & 1 & 2 \\
\hline U of Colorado - Boulder & 1 & & & & & & & & & & 2 & & & & & \\
\hline U of Colorado - Denver & 1 & 2 & & & 1 & & 1 & & 5 & & 2 & & 1 & 1 & & 1 \\
\hline U of Denver $(\mathrm{CO})$ & 2 & 3 & & 2 & 1 & 1 & & 1 & & 1 & 2 & 3 & & 5 & 3 & 7 \\
\hline U of Montana - Western (Dillon) & & & & & & & & & & & & & & & & 1 \\
\hline U of New Mexico (Albuquerque) & 1 & 1 & & & & & 1 & & 2 & & 2 & & 1 & & & 2 \\
\hline U of Texas - El Paso & 1 & 1 & & & & & & & & & & & 1 & & & \\
\hline U of Utah (Salt Lake City) & 1 & 2 & 1 & & & & 1 & 1 & & & 2 & & 3 & & & 1 \\
\hline U of Wyoming (Laramie) & & & & & & 1 & 3 & & 2 & & 1 & & 3 & & & 2 \\
\hline $\begin{array}{l}\text { U.S. Air Force Acad (USAF } \\
\text { Academy, CO) }\end{array}$ & & & & & & & & & & & & & 1 & & & \\
\hline Utah St U (Logan) & 1 & 2 & & & & & 1 & 1 & 2 & & & & 1 & 1 & & 1 \\
\hline Utah Valley St Coll (Orem) & & & & & & & & & & & & & & 7 & & \\
\hline Weber St U (Ogden, UT) & 1 & & & & & & & & & & & & & & 2 & \\
\hline $\begin{array}{l}\text { Westminster Coll (Salt Lake City, } \\
U T)\end{array}$ & & & & & & & & & & & & & & 6 & & \\
\hline TOTALS & 18 & 18 & 3 & 2 & 3 & 6 & 23 & 4 & 20 & 4 & 14 & 4 & 26 & 56 & 16 & 36 \\
\hline
\end{tabular}

1 = general; 2 = analytical; 3 = intelligence; 4 = economics \& finance; $5=$ environmental issues; $6=$ geography; $7=$ highways; $8=$ transit; $9=$ traffic; $10=$ land use; $11=$ community $\&$ regional planning; $12=$ laws, regulations $\&$ administration; 13 = pavement; 14 = air; 15 = freight; $\mathrm{O}=$ "other." The numbers include undergraduate, graduate, and undergraduate-graduate courses. 


\section{Research}

As discussed under "Background," the success of many transportation programs is based on the ability to establish and maintain a research program. One gauge of activity in transportation research is participation in the University Transportation Centers Program (UTCP), which was established by the U.S. Department of Transportation in 1987 to "promote individual initiatives and scientific innovation in a variety of transportation modes and disciplines" (20). The program was reauthorized in 1998, by the Transportation Equity Act for the $21^{\text {st }}$ Century, for an additional six years (21). As of 1998, there were 14 UTCP centers: ten regional and four national. There were 64 participating universities. One of the UTCP regions, the Mountain-Plains Consortium, incorporates three of the institutions within the study region: Colorado State University, the University of Utah, and the University of Wyoming. Two additional universities, Montana State University - Bozeman and the University of Denver, were also being funded through the UTCP. The research conducted for this paper did not attempt to examine the extent of other research funding sources at these and the other institutions.

Involvement in the annual meeting of the Transportation Research Board (TRB) was also investigated as an indicator of institutional research activity. The TRB conference, held every January in Washington, DC, is the largest single gathering of transportation researchers, practitioners, and officials in the U.S. Attendance at the most recent meetings has exceeded 8,000 , with over 1,000 papers and a total of nearly 2,000 presentations, workshops and committee meetings on a wide variety of transportation topics. Participation in the conference is worldwide in scope. The number of presentations and workshops with which an institution was involved served as a proxy for other measures of research activity, such as funding amounts, doctoral degrees granted, publications by faculty, and citations of faculty writings.

Participation by mountain region institutions in the 2002 and 2003 TRB meetings was investigated. A total of 18 institutions - representing a subset of the 40 offering transportation coursework - were involved in one or both of the TRB conferences. The level of involvement ranged from one session or workshop (Boise State University, South Dakota School of Mines and Technology, University of Denver) to 20 (University of Arizona). The tallies are presented in Table 4. The five UTCP institutions were among the 18 involved in the TRB meeting. The 18 institutions represented $45 \%$ of all those offering transportation coursework, and $9.7 \%$ of all two- and four-year schools in the study region. These figures might be indicative of the amount of transportation research activity within the mountain region. Fifteen of the 18 institutions were offering one or more graduate degrees in one or more transportation-related fields. Three of the institutions were offering bachelor's degrees only in transportation-related fields, but were nonetheless producing reportable research findings.

\section{Assessment of Transportation Programs}

The predecessor paper to the current one (4) developed a method for scoring transportation programs based on a number of teaching- and research-related factors. A similar approach was not used in this paper because of the rudimentary and arbitrary nature of the scoring system. Further study is needed to develop a defensible method of "rating" transportation programs. It is, perhaps, not critical to "rank" or "score" programs; it is important, though, to identify programs that can offer the student comprehensive coursework in transportation, a degree in a transportation-related field, and research support. Table 4 summarizes the 40 study region insti-

Proceedings of the 2004 American Society for Engineering Education Annual Conference \& Exposition Copyright @ 2004, American Society for Engineering Education 
Table 4. Transportation Teaching, Degrees \& Research: Colleges \& Universities in the Mountain Region

\begin{tabular}{|c|c|c|c|c|c|}
\hline College or University & Courses & Essential Areas & Degrees & TRB: 2002-03 & UTC \\
\hline Arizona St U (Tempe) & 27 & 10 & 9 & 12 & \\
\hline Black Hills St U (Spearfish, SD) & 1 & 0 & 0 & 0 & \\
\hline Boise St U (ID) & 9 & 6 & 2 & 1 & \\
\hline Brigham Young U (Provo, $U T)$ & 7 & 6 & 3 & 6 & \\
\hline Carroll Coll (Helena, MT) & 1 & 1 & 1 & 0 & \\
\hline Chadron St Coll $(N E)$ & 2 & 1 & 0 & 0 & \\
\hline Colorado Sch of Mines & 0 & 0 & 1 & 4 & \\
\hline Colorado St U (Ft. Collins) & 1 & 1 & 3 & 4 & $\bullet$ \\
\hline Colorado St U - Pueblo & 2 & 1 & 1 & 0 & \\
\hline DeVry U (Colorado Springs, CO) & 1 & 1 & 0 & 0 & \\
\hline DeVry U (Phoenix, AZ) & 1 & 1 & 0 & 0 & \\
\hline Embry-Riddle Aeronautical U (Prescott, $A Z$ ) & 3 & 1 & 1 & 0 & \\
\hline Idaho St U (Pocatello) & 4 & 1 & 1 & 0 & \\
\hline Metro St Coll of Denver $(\mathrm{CO})$ & 22 & 4 & 2 & 0 & \\
\hline Montana St U - Bozeman & 7 & 6 & 2 & 10 & $\bullet$ \\
\hline Montana St U - Northern (Havre) & 11 & 1 & 1 & 0 & \\
\hline Montana Tech of The U of Montana (Butte) & 1 & 1 & 1 & 0 & \\
\hline $\begin{array}{l}\text { New Mexico Inst of Mining \& Tech } \\
\text { (Socorro) }\end{array}$ & 1 & 1 & 0 & 0 & \\
\hline New Mexico St U (Las Cruces) & 3 & 3 & 4 & 8 & \\
\hline Northern Arizona U (Flagstaff) & 2 & 2 & 1 & 3 & \\
\hline Phoenix College $(A Z)$ & 1 & 1 & 1 & 0 & \\
\hline Pueblo Comm Coll $(\mathrm{CO})$ & 2 & 2 & 1 & 0 & \\
\hline Rocky Mountain Coll (Billings, MT) & 10 & 1 & 1 & 0 & \\
\hline Salt Lake Comm Coll (UT) & 7 & 2 & 2 & 0 & \\
\hline $\begin{array}{l}\text { South Dakota Sch of Mines \& Tech } \\
\text { (Rapid City) }\end{array}$ & 1 & 1 & 1 & 1 & \\
\hline Southern Utah U (Cedar City) & 1 & 0 & 0 & 0 & \\
\hline U of Arizona (Tuscon) & 11 & 8 & 5 & 20 & \\
\hline U of Colorado - Boulder & 3 & 2 & 3 & 3 & \\
\hline U of Colorado - Denver & 15 & 8 & 4 & 7 & \\
\hline U of Denver $(\mathrm{CO})$ & $31^{*}$ & 11 & 1 & 1 & $\bullet$ \\
\hline U of Montana - Western (Dillon) & 1 & 0 & 0 & 0 & \\
\hline U of New Mexico (Albuquerque) & 10 & 6 & 4 & 4 & \\
\hline U of Texas - EI Paso & 3 & 3 & 2 & 5 & \\
\hline U of Utah (Salt Lake City) & 12 & 7 & 3 & 15 & $\bullet$ \\
\hline U of Wyoming (Laramie) & 12 & 5 & 3 & 8 & $\bullet$ \\
\hline U.S. Air Force Acad (USAF Academy, CO) & 1 & 1 & 1 & 0 & \\
\hline Utah St U (Logan) & 10 & 7 & 5 & 9 & \\
\hline Utah Valley St Coll (Orem) & 7 & 1 & 1 & 0 & \\
\hline Weber St U (Ogden, UT) & 3 & 2 & 1 & 0 & \\
\hline Westminster Coll (Salt Lake City, UT) & 6 & 1 & 1 & 0 & \\
\hline
\end{tabular}

The course column includes undergraduate, graduate, and undergraduate-graduate courses. University of Denver (*) courses are quarter-length (all others are semester-length). The number of degrees includes those offered in transportation-related fields. The TRB column features a tally of the number of presentations and workshops in which the institution was involved in the 2002 and 2003 annual conferences. UTC = University Transportation Centers. The institutions in bold have entries in at least four of the five columns. 
tutions in five areas: the number of transportation courses offered, the number of essential transportation topics covered by the courses offered, the number of degrees offered in transportrelated fields, the level of participation in the 2002 and 2003 TRB meetings, and membership in the UTCP. A total of 17 institutions, shown in bold in Table 4, have entries in four of these five areas. These 17 colleges and universities form the "top tier" among mountain region institutions, perhaps, for study and research in transportation.

Based on the criteria established in this paper, in terms of the number of courses and degrees offered, Arizona State University offers the widest selection to the transportation student. In terms of the extent of coverage of the essential transportation topics, the University of Denver offers the greatest breadth of coursework. In terms of research activity, the University of Arizona has the highest level of involvement, based on participation in the year 2002 and 2003 TRB meetings. A tabulation of TRB activity over a longer period of time would be needed to ascertain the consistency of this university's involvement.

\section{Rating Transportation Programs}

To distinguish between the 17 "top tier" mountain region institutions, a rating system would be needed. This paper, as indicated earlier, does not develop and apply such a system - another study would be warranted. Some of the concerns of a rating system, though, might be as follows:

Undergraduate vs. Graduate Courses. The transportation courses summarized in Tables 2-4 do not distinguish between those available to undergraduate, graduate, and undergraduate-graduate students. It is recognized that a graduate-level course in transportation should carry greater "weight" than an undergraduate course because of the greater depth of coverage, higher expectations for the students, and more analytically challenging material. It is not readily clear, though, what the relative weightings of graduate, undergraduate-graduate, and undergraduate courses should be. Some of the considerations would be the amount of reading required, the number of hours expected of the student outside of class, and the financial value per credit-hour awarded to a department per student enrolled.

Frequency of Course Offerings. Not considered in this paper's discussion is the frequency with which certain transportation courses are offered. This can vary greatly from institution to institution, and is generally a function of the total number of courses offered relative to the number of transportation faculty. The frequency may also be dependent on the level of student demand. A course that is offered annually should, perhaps, be given greater weight than one that is offered bi- or triennially.

Course Credit-Hours. Also not considered in this paper is the number of credit hours assigned to each course. The credit-hours system can vary between institutions. At the University of Utah, for example, undergraduate and graduate engineering courses are typically worth three credithours: the student typically spends three hours per week in class. Courses that have laboratory sessions are usually worth four credit-hours, although the additional hour is not necessarily commensurate with the amount of time spent in lab. 
Research Activity. As indicated earlier, the appropriate method for evaluating transportation research activity is not clear. Involvement in the UTCP and the annual meetings of the TRB was used here, but there are other measures. These would include financial measures, such as the amount of research funding or the number of funded projects, as well as research products, such as publications by and citations of the faculty. The number of transportation-themed dissertations and theses completed might also be a measure of the level of research.

Faculty. Although Cottrell (4) addressed the number of full-time transportation faculty at each institution, this paper did not attempt to summarize this statistic. In the research done for the current paper, it was observed that some universities with transportation courses did not have full-time transportation faculty. At other institutions, it was not readily clear who among the faculty was responsible for transportation courses. Further, at some schools, such as the University of Utah, some transportation-related research was being performed by non-transport faculty. Cottrell also observed that the impact of faculty turnover on the number and frequency of course offerings was evident at some institutions after just one year. Given the inconsistencies in identifying transport faculty, as well as the limitations associated with isolating certain faculty as transportation "only," the faculty component was not incorporated into this paper. A more indepth study, possibly involving contacts with the individual institutions, would be needed to identify the transportation-related instructors and researchers. The contacts would also be a useful way to verify the information provided online.

Combining Teaching, Degrees Granted, and Research. Perhaps the most challenging aspect of developing a rating system for transportation programs is to score teaching, degrees granted, and research activity using similar units on a normalized scale. One approach might be to establish a minimum, maximum or desirable threshold for each program component, then normalize all

scores to that threshold. For example, the maximum threshold for essential transportation topics covered by coursework is to have all 15 topics represented. The normalized threshold would be 100.0; the University of Denver's rating, based on covering 11 of 15 essential subjects, would be 73.3. A desirable threshold might be to cover, say, 8 or 10 of the essential topics. Further study is needed to determine an appropriate threshold. Similarly, a desirable threshold for degrees granted might be to have at least one bachelor's, master's, and Ph.D. program in one or more transportation-related fields. Programs awarding the three degrees - not necessarily in the same department - would rate a score of 100 . Institutions granting more than three degrees in transportation-related fields would be rewarded with scores higher than 100 .

Another technique would be to study the transportation programs at institutions that are regarded in industry as among the strongest in the U.S. These might include the University of California, Berkeley, the Georgia Institute of Technology, and several others. The number of transportation courses offered, essential topics covered, degrees granted in transportation-related fields, and research activity at these institutions might identify upper-end standards to which all other institutions could be compared.

\section{Conclusion}

The research conducted for this paper found that 40 of the 185 two- and four-year institutions in the mountain region of the U.S. were offering at least one course in transportation. Four of the 40 institutions were two-year colleges. Four of the institutions were offering 15 or more 
transportation courses, including Arizona State University, Metropolitan State College of Denver, the University of Colorado - Denver, and the University of Denver. Fifteen transportation topics were identified as being essential to a comprehensive transportationlearning environment. No institution was offering coursework in all 15 areas, but the University of Denver had courses in 11 of the topics, while Arizona State University was covering ten. A total of 42 institutions were offering at least one degree in a transportation-related field, although only 32 of these had transportation coursework, excluding courses in vehicle maintenance and technology, tourism management, and vehicle and airplane operations. Of these 32 institutions, the highest degrees being offered in transportation-related fields were associate's degrees at four schools, bachelor's at twelve, master's at four, and doctorates at twelve. Institutional involvement in the annual TRB meeting was used as a gauge of transportation research activity. A total of 18 institutions were involved in some aspect of this conference - presentation, paper, workshop, poster, or otherwise - in 2002 and 2003. The paper did not attempt to "rank" the institutions, but 17 schools were identified as meeting four of the five following "requirements:"

- One or more courses in transportation were being offered;

- One or more of the 15 essential transportation topics were covered by coursework;

- One or more degrees were being granted in a transportation-related field (aviation, city and regional planning, civil engineering, civil engineering technology, transportation engineering technology, or transportation management or systems);

- There was participation in at least one session or workshop at the 2002 or 2003 TRB annual meetings; and

- The institution was participating in the University Transportation Centers Program.

The 17 "top tier" institutions include Arizona State University, Boise State University, Brigham Young University, Colorado State University, Montana State University - Bozeman, New Mexico State University, Northern Arizona University, South Dakota School of Mines and Technology, University of Arizona, University of Colorado - Boulder, University of Colorado Denver, University of Denver, University of New Mexico, University of Texas - El Paso, University of Utah, University of Wyoming, and Utah State University.

The information reported in this paper applies to the 2003-2004 academic year. Academic programs are regularly modified with the loss or addition of faculty members, and the addition and deletion of courses. Similarly, transportation research programs can either be initiated or terminated. It was estimated that at least four full-time transportation faculty would be needed to cover all 15 of the essential transportation topics. In a small program, the loss of one faculty member can be very disruptive, if only temporarily. It is critical that this type of study be updated regularly. It would be useful to use a similar methodology to perform a nationwide examination of transportation engineering and planning education. The project could even be extended to include international programs.

\section{Acknowledgement}

Although not listed in the bibliography, the author consulted numerous on-line catalogs and departmental websites from the 185 colleges and universities considered in this paper. 


\section{Bibliography}

1. M.L. Goldberger, B.A. Maher, and P.E. Flattau. Research-Doctorate Programs in the United States: Continuity and Change. National Research Council, Washington, D.C., 1995.

2. America's Best Colleges and Best Graduate Schools. In U.S. News and World Report. Washington, D.C., 2003 (two issues).

3. J.C. Angus, R.V. Edwards, and B.D. Schultz. Ranking Graduate Programs: Alternative Measures of Quality. In Chemical Engineering Education, Winter 1999, pp. 72-83.

4. W.D. Cottrell. Transportation Education at Universities in the Western U.S. In Proceedings, $79^{\text {th }}$ Annual Meeting of the Transportation Research Board, Washington, DC, January 10-14, 2000 (on CD-ROM).

5. F.B. Francois. Keynote Address, Chairwoman's Luncheon, $78^{\text {th }}$ Annual Meeting of the Transportation Research Board, Washington, D.C., January 13, 1999.

6. ITE Technical Council Committee 2-32. Attracting Students to a Professional Career in Transportation Engineering. In ITE Journal, Vol. 60, No. 1, January 1990, pp. $42-48$.

7. E. Beimborn. Transportation Education: University Degree Programs. In Transportation Research Board Special Report 210: Transportation Education and Training -- Meeting the Challenge. Proceedings of the Conference on Surface Transportation Education and Training, Williamsburg, VA, October 28-31, 1984, pp. 138-147.

8. L. Pignataro and L.A. Hoel. College and University Transportation and Logistics Programs. In Proceedings 17, Intermodal Transportation Education and Training. Transportation Research Board, Washington, DC, November 2-5, 1997.

9. H.J. Van Zuylen. Multidisciplinarity in Transport Research and Education. In Journal of the Transportation Research Board: Transportation Research Record 1729. Transportation Research Board, National Research Council, Washington, DC, 2000, p. 75-81.

10. ITE Technical Council Committee 2-33. Suggested Graduate Curricula for Future Transportation Engineers. In ITE Journal, Vol. 60, No. 3, March 1990, pp. 23-25.

11. ITE Technical Council Committee 2-24. Suggested Course Content for Undergraduate Transportation Programs. In ITE Journal, Vol. 58, No. 6, June 1988, pp. 53-54.

12. C.J. Khisty. Undergraduate Transportation Engineering Education. In Transportation Research Record 1101. Transportation Research Board, National Research Council, Washington, DC, 1986, pp. 1-3.

13. K.F. Turnbull. Transportation Planning Education in Urban and Regional Planning Graduate Programs. In Transportation Research Record 1498. Transportation Research Board, National Research Council, Washington, D.C., 1994, pp. 57-64.

14. S. Handy, L. Weston, J. Song, K.M.D. Lane, and J. Terry. The Education of Transportation Planning Professionals. Research Report SWUTC/02/167522, Southwest Region University Transportation Center, The University of Texas at Austin, Austin, TX, October 2002.

15. Four-Year Colleges 2004. $34^{\text {th }}$ edition, Peterson's, Thomson Corporation, USA, 2003.

16. Graduate Schools in the U.S. 2004. Peterson's, Lawrenceville, NJ, 2003.

17. The World Almanac and Book of Facts 2003. World Almanac Books, New York, NY.

18. L.G. Grimm and R.P. Elliott. Accreditation of Programs in Transportation Engineering: The University of Arkansas Experience. In Transportation Research Record 1659. Transportation Research Board, National Research Council, Washington, DC, 1999, pp. 141-144.

19. ITE Transportation Education Council. Undergraduate and Graduate Transportation Programs Directory, 1988.

20. U.S. Dept. of Transportation. University Transportation Centers Program 1998 (pamphlet).

21. Federal Highway Administration. TEA-21-Fact Sheet: University Transportation Research, September 14, 1998.

Proceedings of the 2004 American Society for Engineering Education Annual Conference \& Exposition Copyright (C) 2004, American Society for Engineering Education 